NEW WORLD

\title{
Furtive Search for Cancer Head
}

\section{by our Washington Correspondent}

THE executive talent scouts at the White House are combing the land for a politically acceptable name to put at the head of the Cancer Cure Programme, the National Cancer Bureau, or whatever fancy name the present National Cancer Institute may end up with. At least in financial terms, the new post will be one of the most influential in the field of biomedicine, since its holder will dispose of funds totalling some $\$ 330$ million in the present fiscal year with promises of still greater largesse to come.

One of the leading candidates at present is Albert Sabin, developer of polio vaccine and now director of the Weizmann Institute in Israel. Several others under consideration, including R. Lee Clark of the M. D. Anderson Hospital in Houston, are members of the panel of consultants on the Conquest of Cancer, a group of fund raisers and cancer specialists which set in train the movement for an expanded financing of cancer research. The panel's advocacy of an independent cancer agency outside the National Institutes of Health was adopted by Senator Edward Kennedy and at first opposed. by the Nixon Administration which sought to buy off the Kennedy plan by requesting from Congress an extra $\$ 100$ million for cancer research.

Last month Kennedy's health subcommittee agreed on a compromise bill that is in essence the Kennedy plan for an independent agency. The degree of independence from the NIH, however, seems to have been left unclear in the bill, and may to a large extent depend on the man who is appointed director of the agency.

The Nixon team searching for a director apparently includes James Cavanagh, a member of the White House staff, Elliot L. Richardson, Secretary of the Department of Health, Education and Welfare, Jonathan Moore, a counsellor to Richardson, and Edward E. David, the President's science adviser. The search process seems to be being conducted in a closehanded way, with various interested parties being asked to suggest candidates but given no indication of how the search is progressing. If true to Administration form, the successful candidate will have to be a Republican or at worst a neutral Democrat. A major issue has been whether the director should be a scientist or a manager. The panel of consultants, whose individual views have been listened to by the Administration, stressed the importance of applying management techniques to the solution of cancer, and a candidate who combined administrative skills with a scientific reputation, preferably in or near the cancer field, would be an obvious choice.

Early in the selection procedure, a list of about fifteen names was in circulation, some of them non-scientists and many drawn from the twenty-sixmember panel of consultants. Panel members said to be under consideration have included Henry S. Kaplan, chairman of the radiology department at Stanford University, R. Lee Clark, head of the M. D. Anderson hospital in Houston, Benno C. Schmidt, an investment banker who chaired the panel, Joseph Burchenal, vice-president of the Sloan-Kettering Institute for Cancer Research, and Joshua Lederberg, Nobel laureate and Stanford geneticist.

Two months ago, when President Nixon announced in an attempt to fight off the Kennedy bill that the National Cancer Institute would be elevated into a bureau within the NIH, the Administration's choice for head of the bureau was Kaplan. Kaplan later withdrew his name and the search had to begin again, doubtless made harder by the obvious political pressures to which, under the prevailing arrangements, the director will be exposed. Sabin, who seems to be one of the leading candidates, has already had discussions with David, the President's science adviser, and with people at the National Cancer Institute.

But Sabin said from Brussels; where he was staying early this week, that he has not been offered the job and he would "have to wait and see" if the offer were made. Sabin, who is setting up a multi-disciplinary cancer centre at Rehovot, said he believes that basic, non-target research in the biomedical sciences is "fairly well funded" at present and that the new money made available for cancer should go into targeted research programmes, not least as a trial of what scientists can do to apply their skills to national problems. These views are much in line with David's utterances on the question. Sabin also believes that the cancer operation must remain intimately tied to the National Institutes of Health, especially with respect to the processing of grant applications.

Clark, another prominent candidate, is said to have the backing of the panel of consultants and is known for his administrative as well as fund-raising adeptness. But although Clark has more support than other candidates, he also has more opposition, in part, it seems, through fear of the same qualities. Clark is a believer in the power of management techniques and advocates that a master plan for cancer should be drawn up using such tools as time phase analysis. Clark said last week that he believed the job called for both a scientist and an administrator.

Among the scientific community probably a majority would prefer the new cancer effort to be headed by a scientist of merit who is also knowledgeable about cancer-James D. Watson, director of the Cold Spring Harbor laboratory, is one name mentioned as an example. Others believe that the new director need only be a figurehead who goes down well with Congress but would leave the scientific operation of the institute alone. At one time there were plans to announce the choice for the appointment on July 1 , the date on which the extra $\$ 100$ million requested by the Administration at an earlier stage in its skirmish with Kennedy becomes available for spending. It now seems that the appointment may be postponed until the Kennedy bill, now adopted by the Administration in essential outline, has passed further through the Congressional mill and the structure of the new agency is somewhat better defined.

\section{MANPOWER}

\section{PhDs in Surplus}

by our Washington Correspondent

For the past seven years, federal officials have ignored the warnings of outsiders that the educational system was churning out PhDs at such a rate that the supply would soon exceed the demand. The Office of Education, for example, not the brightest assembly of wit in the federal government, was predicting in 1964 that there would be a cumulative deficit of $125,000 \mathrm{PhDs}$ by 1974. It has taken almost the actual appearance of jobless PhDs to convince the forecasters that they were wrong. The National Science Foundation has now come into line with a projection* that calculates a sizable surplus of doctoral scientists and engineers-between 18,000 and 66,000 -by 1980 .

Between 315,000 and 336,000 doctorate holders in science and engineering will be available to the US economy

*1969 and 1980 Science and Engineering Doctorate Supply and Utilization. US Government Printing Office, Washington DC 20402. 50 cents. 